\title{
16
}

\section{Lessons and legacies of the war in Afghanistan}

\author{
William Maley
}

In 1897, Rudyard Kipling penned some verses to mark Queen Victoria's Diamond Jubilee. Kipling is often seen as virtually the poet laureate of British 19th-century imperialism, but his words on this occasion, a poem called Recessional, offered a warning against the sin of hubris:

Far-called, our navies melt away,

On dune and headland sinks the fire,

Lo, all our pomp of yesterday,

Is one with Nineveh and Tyre!

Judge of the Nations, spare us yet,

Lest we forget-lest we forget.

It is quite common at conferences dealing with Afghanistan to hear some speaker quote Kipling's words about that country, although Kipling never set foot in Afghanistan, and images of Afghanistan in the 19 th century offer a poor guide to the complexities of Afghanistan in the 21st century. Kipling's Recessional, however, does have some lessons to offer. One is that military power can be a crude tool for realising political objectives. Another is that well-intentioned actions can have unintended consequences. But a third, perhaps not intended by Kipling, is that how one assesses particular actions might crucially depend upon the point in time at which one attempts an assessment. This was captured in Hegel's famous comment that the Owl of Minerva spreads her wings only when dusk is setting, and in the remark of Zhou Enlai, who, when asked what he 
thought was the main consequence of the French Revolution, responded that it was too soon to tell. Today there is no shortage of works, some of high quality, proclaiming the international enterprise in Afghanistan after 2001 to have been a failure. ${ }^{1}$ This judgement, however, might be premature. While no one would dream of pronouncing it a dazzling success, the jury is ultimately still out, and large numbers of Afghans have no desire to return to the environment that confronted them before Operation ENDURING FREEDOM overthrew the Taliban regime in October and November 2001.

In seeking to draw lessons from experience in Afghanistan, inevitably different observers will come up with different conclusions. This is in part because various actors involved in the Afghanistan theatre became engaged on the basis of different interests and values. But that said, it is worthwhile to pay some attention to the attitudes of ordinary Afghans, whose perspectives are almost always omitted from explorations of this kind. Yet we have clearer windows into their thinking than we often have into the policy processes of Western countries that became involved in Afghanistan. Since 2004, the Asia Foundation has been conducting rigorous surveys of mass opinion in Afghanistan, and the results are quite illuminating. An enduring question has related to the mood in Afghanistan, with respondents being asked whether they thought things in Afghanistan were going in the right direction or in the wrong direction. In 2004, the mood was one of optimism: 64 per cent responded positively and only 11 per cent negatively. There was a stark shift by 2006; the percentage responding positively had dropped to 44 and the percentage responding negatively had risen to 21 . From 2008, perceptions steadily improved, with those positively inclined rising from 38 per cent in 2008 to 58 per cent in 2013 , although the percentage with a negative view also rose, from 32 per cent to 37 per cent. With the substantial withdrawal of foreign forces, however, the national mood again took a turn for the worse: in 2017, fully 61 per cent concluded that things were going in the wrong direction, with only 33 per cent of the view that things were going in the right direction. ${ }^{2}$

1 See for example N. Coburn, Losing Afghanistan: An Obituary for the Intervention, Stanford University Press, Stanford, 2016; F. Ledwidge, Losing Small Wars: British Military Failure in the 9/11 Wars, Yale University Press, New Haven, 2017; and A.B. O'Connell (ed.), Our Latest Longest War: Losing Hearts and Minds in Afghanistan, University of Chicago Press, Chicago, 2017.

2 Asia Foundation, Afghanistan in 2017: A Survey of the Afghan People, Asia Foundation, Kabul, 2017, p. 203. 


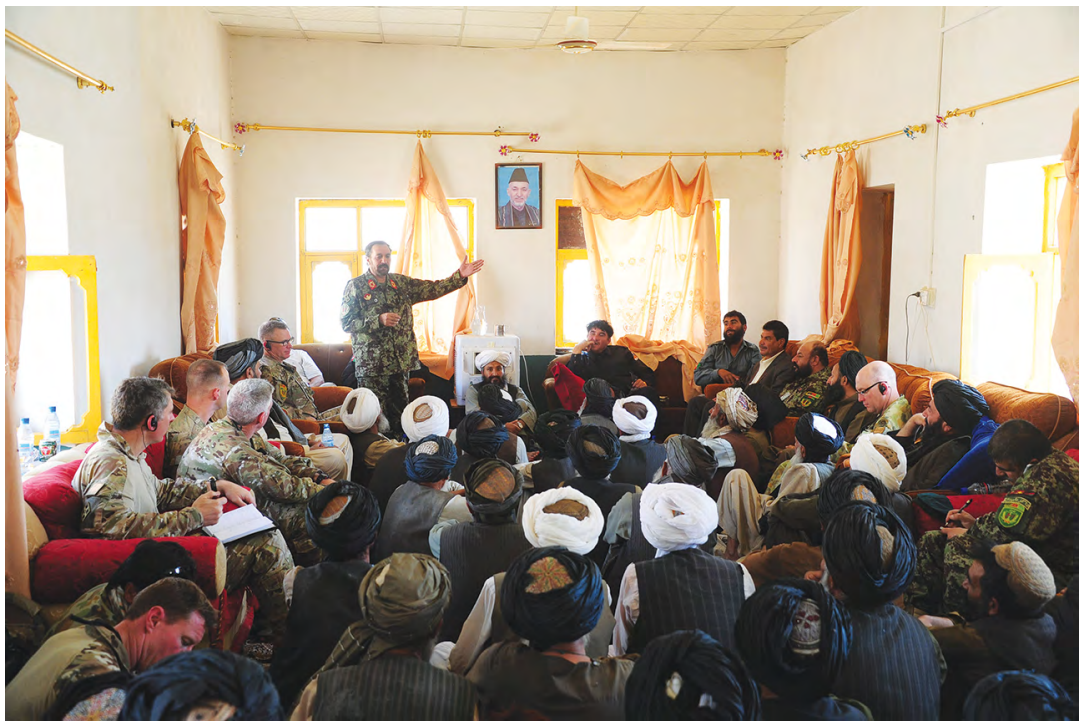

Major General Abdul Hamid, Commander 205th Hero Corps, Afghan National Army, addresses tribal elders at a Shura held at an Afghan National Army base in Chah Chineh, Afghanistan, 2013.

Source: Courtesy of the Department of Defence.

Interestingly, the two main plunges in confidence took place when international attention shifted away from Afghanistan, with the deterioration of the US position in Iraq in 2005-06, and with the completion of transition in Afghanistan at the end of 2014. Whether this represented causation or merely correlation is difficult to tell, but it does suggest that when international forces substantially withdrew from Afghanistan, ordinary Afghans were not cheering the process.

In the remarks that follow, my aim is to focus on some specific lessons for military deployments that might be of value to the Australian Defence Force $(\mathrm{ADF})$ in the future, as well as on the ongoing problem of insurgency and on questions related to where Afghanistan might go from here. Before doing so, however, there are two overarching observations about the situation in Afghanistan that are potentially relevant to other conflict zones in which Australian forces could be deployed.

First, Afghanistan since 2001 has been exposed to the forces of globalisation to a greater extent than virtually any other country in the world. The effects have been all the more dramatic because of the extent of the isolation of the country during the period of Taliban rule following 
the fall of the Afghan capital in September 1996. ${ }^{3}$ Opening Afghanistan to the wider world has been one of the greatest achievements wrought by the international presence in the country. With 70 per cent of the settled population under the age of $30,{ }^{4}$ the scope for the Afghan population to prove receptive to new ideas and new ways of proceeding might be somewhat greater than is often thought. The crucial point to note here is that military deployments do not take place in an environment that is frozen and fixed. On the contrary, the context of deployments is almost always one that is subject to dynamic forces at a number of levels. From a longer-term point of view, societies are in a process of near-constant change and adjustment while, on a day-to-day basis, individual actors are routinely reconfiguring and renegotiating their relationships and recalculating what kind of alignments will best serve their interests in the absence of the kind of certainties that the existence of a consolidated state can offer.

Second, the psychology of the situation in a fraught environment such as that of Afghanistan could be absolutely central to the success or failure of international interventions. ${ }^{5}$ Put bluntly, it does not pay to be on the losing side if one is an ordinary Afghan, and the importance of military deployments might lie not so much in what they physically achieve but in the wider psychological climate that they foster. This, in turn, will depend to some extent on how well international militaries understand the minutiae of their operational environment. Given the complexity of Afghan society, mastering such detail would be no easy task, ${ }^{6}$ but failure in this sphere can lead to misdiagnosis of conflict formations, with serious ramifications for the effectiveness of both kinetic operations and reconstruction activities.

3 See H. Mohammadi, Tasir-e jahanishodan bar farhang dar Afghanistan, Entesharat-e Farhang, Kabul, 2014.

4 Central Statistics Organization, Afghanistan Statistical Yearbook 2016-17, CSO, Kabul, 2016-17, p. 5 .

5 W. Maley, 'Afghanistan on a knife-edge', Global Affairs, vol. 2, no. 1, 2016, pp. 57-68.

6 See W. Maley, 'Studying host-nationals in operational areas: The challenge of Afghanistan', in Routledge Handbook of Research Methods in Military Studies, ed. J. Soeters, P.M. Shields and S. Rietjens (eds), Routledge, London, 2014, pp. 53-64. 


\section{Some lessons for military deployments}

There are a large number of lessons one might potentially extract from the international deployment in Afghanistan from 2001, and different analysts will likely produce different lists. The following seven points therefore are in no sense definitive; they simply reflect what this writer considers worth canvassing with an interested audience.

First, military deployments always need to be linked to a political strategy. One of the enduring criticisms of the international involvement in Afghanistan after 2001 was that, following the overthrow of the Taliban regime, the precise aims of international action were relatively unclear, leading to improvisation on the ground and contradictory assertions at the higher policy level as to the purpose of the mission. ${ }^{7}$ This does not foster the confidence on the ground on the part of locals that should be central to any such mission to encourage, and it can lead soldiers to be deeply frustrated at the wilderness of mirrors in which they seem to be living. This of course is not a problem that militaries can resolve on their own; rather, it depends upon the willingness and ability of senior political leaderships to develop a coherent image of what they are seeking to do. Great wartime leaders, such as Winston Churchill, are almost always individuals who prove capable of articulating and driving a grand strategic vision that offers a pathway for achieving defensible and desirable goals. In the Afghanistan case, part of the problem was that there was no Churchill on hand to perform this task, and another was that the countries contributing forces to Afghanistan did not see themselves as being on a war footing.

Second, it is not possible to stabilise a disrupted state such as Afghanistan on a province-by-province basis. The Provincial Reconstruction Team (PRT) approach that took shape in Afghanistan provided some opportunity to do good for some people, but it neither constituted a coherent model for reconstruction activity nor supplied a workable framework for addressing the problem of ambient insecurity. The 'ink spot' theory positing that local stability, created by the deployment of a PRT to a particular area, might then spread more widely proved to be ill founded for several reasons. On the one hand, while Afghans are not ingrates, they are also not inclined to align themselves politically on the basis of gratitude for what

7 See S. Rynning, NATO in Afghanistan: The Liberal Disconnect, Stanford University Press, Stanford, 2012; and D.P. Auerswald and S.M. Saideman, NATO in Afghanistan: Together, Fighting Alone, Princeton University Press, Princeton, 2014. 
has been done for them in the past rather than on the basis of a rational calculation of what is likely to happen to them in the future. On the other hand, there is evidence that in areas that were already contested between the government of Afghanistan and the armed opposition, aid was more likely to aggravate conflict than defuse it, providing 'soft' targets for attack and inspiring the enemy to concentrate its firepower. ${ }^{8}$ Both of these considerations worked against aid delivery producing a significant political dividend.

Third, in a number of further senses, aid can act as a fuel for conflict rather than function as a flame retardant. In many parts of Afghanistan, there are long-standing, ongoing conflicts that do not fit easily into a simple model of enmity between the Afghan Government and the Taliban. ${ }^{9}$ International actors might inadvertently find themselves injecting resources into conflicts of this kind, conflicts of the dynamics and dimensions of which they are blissfully unaware. For example, the Helmand Food Zone Programme, trumpeted as a major counter-narcotics endeavour, ended up feeding the patronage networks of the provincial governor, ${ }^{10}$ in a way that was profoundly corrupting of Afghanistan's wider state-building enterprise. ${ }^{11}$

Fourth, 'stability' can prove remarkably tenuous. The classic example of this was the fall of the town of Kunduz to Taliban forces for a fortnight from 28 September 2015. Kunduz was not a hamlet in the middle of nowhere. It was a strategically important urban centre where a German PRT had been deployed for a considerable period of time. ${ }^{12}$ Through much of 2015, the situation in the vicinity of the town had been deteriorating, but this meant that when it eventually did fall to the Taliban, it was hardly an event that came out of the blue. ${ }^{13}$ The human consequences for

8 R. Sexton, 'Aid as a tool against insurgency: Evidence from contested and controlled territory in Afghanistan', American Political Science Review, vol. 110, no. 4, 2016, pp. 731-49.

9 M. Martin, An Intimate War: An Oral History of the Helmand Conflict, Hurst \& Co., London, 2014.

10 D. Mansfield, A State Built on Sand: How Opium Undermined Afghanistan, Hurst \& Co., London, 2016, pp. 225, 242.

11 S. Chayes, Thieves of State: Why Corruption Threatens Global Security, W.W. Norton, New York, 2015, pp. 59-60.

12 See W. Maley, 'Civil-military interaction in Afghanistan: The case of Germany', in Reconstructing Afghanistan: Civil-Military Experiences in Comparative Perspective, ed. W. Maley and S. Schmeidl, Routledge, London, 2015, pp. 98-109.

13 M. Kamal, 'L'offensive de Koundouz: Le contexte militaro-stratégique', Les Nouvelles d'Afghanistan, vol. 151, pp. 7-11. 
ordinary Afghans were devastating, ${ }^{14}$ and the psychological effect in other parts of Afghanistan proved considerable, even though government forces managed to reassert control over the town from 13 October. The same was true of the fall of the strategic town of Ghazni in August 2018, an event for which the Afghan Government and its backers were not prepared despite clear warning signs, and which sent reverberations through many other parts of Afghanistan. ${ }^{15}$

Fifth, while it might be convenient in the short run to ground one's engagement with the local population in friendships struck with those who appear to be 'strongmen', in the long run this tends to be at the expense of sustainable institutional development. A crucial point to bear in mind in Afghanistan is that when you make a friend, you can also make an enemy. Much political activity in Afghanistan is based on networks, and different networks can be in brutal competition with each other. ${ }^{16}$ But network relations are also in a process of constant renegotiation, and cannot be taken for granted. In 2010, a senior Australian general described the police chief in Uruzgan, Matiullah Khan, as 'our guy'. ${ }^{17}$ This observation was alarming in two critical respects. In Afghanistan, no political actor is ever 'our guy'. Local actors, quite understandably, almost always have objectives of their own that need not coincide with those of their international backers, ${ }^{18}$ and Matiullah certainly had his own agenda. ${ }^{19}$ In addition, individuals are not institutions, and can be eliminated quickly once they have acquired the wrong enemies. This was what happened to Matiullah, who was assassinated in Kabul in March 2015. ${ }^{20}$ A cynic might say that by this time, he had exhausted his usefulness to the ADF; but of course, the relationship between the ADF

14 UNAMA, Human Rights and Protection of Civilians in Armed Conflict: Special Report on Kunduz Province, United Nations Assistance Mission in Afghanistan and United Nations Office of the High Commissioner for Human Rights, Kabul, 2015, pp. 13-18.

15 See N. Azadzoi and R. Nordland, 'Afghanistan says it controls key city, but ravaged streets show otherwise', New York Times, 12 August 2018.

16 See T. Sharan and S. Bose, 'Political networks and the 2014 Afghan presidential election: Power restructuring, ethnicity and state stability', Conflict, Security and Development, vol. 16, no. 6, 2016, p. 616; and T. Sharan, Dawlat-e Shabakahi: Rabeteh-i Qodrat wa Sarwat dar Afghanistan Pas az Sal-e 2001, Vazhah Publications, Kabul, 2017.

17 D. Oakes, 'General defends Afghan warlord ties', Sydney Morning Herald, 7 December 2010.

18 See W.C. Ladwig, The Forgotten Front: Patron-Client Relationships in Counterinsurgency, Cambridge University Press, Cambridge, 2017.

19 S. Schmeidl, The Man Who Would be King: The Challenges to Strengthening Governance in Uruzgan, Netherlands Institute of International Relations Clingendael, The Hague, 2010.

20 A. Ahmed, 'Powerful Afghan police chief is killed in targeted suicide attack', New York Times, 20 March 2015. 
and Matiullah had wider implications for the long-term effectiveness of what Australia had been attempting to achieve in Uruzgan. ${ }^{21}$ The dangers of dependence on individuals is a pervasive one, and was again illustrated with the assassination on 18 October 2018 of the 'strongman' of Kandahar Province, the 39-year-old police chief General Abdul Raziq. ${ }^{22}$

Sixth, time is the ultimate scarce commodity, and it is often in short supply in undertakings such as that in Afghanistan. April 2018 marked the 40th anniversary of the communist coup in Afghanistan that tipped the country into disorder, and it has not enjoyed much serenity since that disastrous event. When a country has experienced four decades of dislocation, it is naïve in the extreme to think that it will be able to rapidly recover from all the accumulated consequences. Yet the time frames of international missions, let alone the domestic politics of the states contributing to them, rarely make much allowance for this, and the consequence can be a neglect of sustainability, a focus on 'quick impact projects', and a reluctance to engage in relationship-building except with what might appear to be existing powerholders.

Seventh, exercises of the kind in which the ADF engaged in Afghanistan might from the point of view of political leaders be almost entirely unrelated to the needs of the people whom nominally one is helping. This is not for one moment to challenge the genuine commitment of Australian personnel at the operational level to aiding the local population of Afghanistan, but simply to recognise that Australia’s strategic narrativeto the extent that it had one of its own at all —was not focused on aiding Afghans but on preventing Afghanistan from being used as a terrorist base for attacks on other peoples, and on consolidating Australia's alliance relationship with the United States. ${ }^{23}$ These are not trivial objectives, and might well have been formulated as they were in order to make the deployment to Afghanistan more palatable to the general public in

21 See also C. Masters, No Front Line: Australia's Special Forces at War in Afghanistan, Allen \& Unwin, Sydney, 2017, pp. 262-3.

22 T. Shah and M. Mashal, 'Taliban assassinate Afghan police chief ahead of elections', New York Times, 19 October 2018.

23 See W. Maley, 'PRT activity in Afghanistan: The Australian experience', in Statebuilding in Afghanistan: Multi-national Contributions to Reconstruction, ed. N. Hynek and P. Marton, Routledge, New York, 2011, pp. 124-38; and W. Maley, 'The war in Afghanistan: Australia's strategic narratives', in Strategic Narratives, Public Opinion and War: Winning Domestic Support for the Afghan War, ed. B. de Graaf, G. Dimitriu and J. Ringsmose, Routledge, New York, 2015, pp. 81-97. 
Australia. However, in treating assistance to the people of Afghanistan simply as a means to some other end, it ran the risk of devaluing them, an experience with which they are all too familiar.

\section{The problem of insurgency}

The great failure of the international enterprise in Afghanistan from 2001 to 2014 was that it at no time came effectively to grips with the principal factor driving ongoing insurgency, namely the availability to the Taliban of operating bases and support in Pakistan. ${ }^{24}$ As recently as 1 March 2016, the Pakistani Adviser to the Prime Minister on Foreign Affairs, Sartaj Aziz, admitted in a presentation to the Council on Foreign Relations in Washington, DC, that the 'leadership' of the Afghan Taliban 'is in Pakistan'. The attack on Kunduz in 2015 was not carried out by a rag-tag peasant army but by what David Kilcullen has called 'professional fulltime fighters, put through rigorous training by experienced instructors in the camps in Pakistan, with uniforms, vehicles, heavy weapons, encrypted radios, and a formal command structure'. ${ }^{25}$ Afghanistan has serious problems of poor governance, but what makes them critical is the ongoing 'creeping invasion' by its neighbour to the east, using surrogates as a tool to try to deny influence in Afghanistan to Pakistan's great regional and geopolitical rival, India. ${ }^{26}$ This problem is not one that Afghanistan is in a position to confront on its own, and nor is it one for the militaries deployed to Afghanistan to solve. Unfortunately, it is also not one that most leaders of states that have contributed forces to Afghanistan have been prepared to take up either, although President Trump has now begun to address it. ${ }^{27}$ The result has been to put Afghanistan in a kind of holding pattern, which it will most likely continue to occupy unless and until diplomatic and political pressure is brought to bear on Islamabad to cease its destructive activities. Ironically, there is a strong interest-based case for Pakistan to do so, since its nurturing of the Afghan Taliban predictably led to the emergence of a Pakistani spin-off that has brought terror and grief

24 See C. Gall, The Wrong Enemy: America in Afghanistan, 2001-2014, Houghton Mifflin Harcourt, New York, 2014.

25 D. Kilcullen, Blood Year: Islamic State and the Failures of the War on Terror, Black Inc., Melbourne, 2016, p. 77.

26 W. Maley, Transition in Afghanistan: Hope, Despair and the Limits of Statebuilding, Routledge, New York, 2018.

27 Z. Khalilzad, 'Why Trump is right to get tough with Pakistan', New York Times, 23 August 2017. 
to different parts of Pakistan. But regrettably, senior Pakistani generals tend to be insulated from the ill-effects of the actions undertaken by their forces.

The consequences within Afghanistan have been dire. Kabul has become an increasingly dangerous place for ordinary Afghans. On 23 July 2016, a peaceful demonstration, largely comprising members of the historically marginalised Hazara ethnic minority, ${ }^{28}$ was struck near Deh Mazang by bombers, and more than 80 participants in the protest were killed. In August 2016, Taliban terrorists attacked the campus of the American University of Afghanistan, killing students and faculty members. ${ }^{29}$ On 8 March 2017, gunmen attacked the Sardar Daud Khan hospital in Kabul, killing doctors and patients. And on 31 May 2017, a massive explosion was triggered near the German embassy in Kabul by a suicide bomber, killing more than 90 people and wounding nearly $500 .^{30}$ Bombings since then have continued to claim lives, especially those of Hazaras. Rural Afghanistan has become even more dangerous, with Hazaras at particular risk when attempting to travel from one part of the country to another. The specific targeting of civilians makes these attacks not just acts of terrorism but also war crimes. It is by no means clear how all this will end.

\section{Where to from here?}

Given the reluctance to confront Pakistan over its meddling in Afghanistan, Western powers have gone down a rather different path, floating instead the idea that Afghanistan can be stabilised through an agreement with the Taliban. A number of the more notable writings of this ilk carry a distinct whiff of fantasy. For example, in March 2017, a former US ambassador to Pakistan, Richard G. Olson, wrote:

Pakistan's cynical support for the Taliban is merely the most visible of the hedging strategies that various neighbours, including the Iranians and the Russians, have adopted to ensure that they

28 N. Ibrahimi, The Hazaras and the Afghan State: Rebellion, Exclusion and the Struggle for Recognition, Hurst \& Co., London, 2017.

29 M. Mashal, M.F. Abed and Z. Nader, 'Attack at university in Kabul shatters a sense of freedom', New York Times, 26 August 2016.

30 M. Mashal, F. Abed and J. Sukhanyar, 'Deadly bombing is among worst of Afghan war', New York Times, 1 June 2017. 
have some armed Afghan faction beholden to their interests. A comprehensive political settlement would remove the security dilemma that drives these counter-productive interventions. ${ }^{31}$

This argument is radically misconceived on three fronts. First, there is no real equivalence between the massive and decisive support that Pakistan provides to the Taliban and the petty meddling in which various circles in Russia and Iran have occasionally engaged. Second, Pakistan's behaviour cannot be understood simply in terms of the idea of a security dilemma: its actions involve more than a response to the structural features of the international system that can generate security dilemmas in their classic form. ${ }^{32}$ Third, a 'comprehensive political settlement' of the kind that Ambassador Olson advocates would need to address not just the situation in Afghanistan but also the bilateral rivalry between India and Pakistan over Kashmir, a rivalry that has defied all endeavours to overcome it since the partition of the subcontinent in 1947. The belief that the Kashmir conflict is ripe for resolution verges on the delusional.

An even more remarkable article on negotiations was penned by another former US official, Laurel Miller, who defined the problem as 'vested interests on all sides in continuing the war', and argued that the United States could influence the Taliban's calculations through 'applying military pressure and offering political opportunity' and 'using our leverage with the Afghan political elite to ensure their commitment to negotiating.' ${ }^{33}$ But there is far more to the conflict in Afghanistan than simply vested interests. The Taliban continue to embody a vision of social order that is anathema to the very groups whose emergence since 2001 the United States and its allies have celebrated, such as educated women, who fear that their gains could be sacrificed as part of a negotiation. ${ }^{34}$ The conflict here is much more one of values than of interests. Furthermore, after the Taliban's abominable behaviour in Kunduz in 2015 and Ghazni in 2018, few Afghans are under any illusions about what creating space for the Taliban might involve, and many would be affronted by the suggestion that the United States has any right to offer 'political opportunity' to the Taliban, especially when the 2017 Asia Foundation survey found

31 R.G. Olson, 'The art of a deal with the Taliban', New York Times, 29 March 2017.

32 See N. Motwani, 'Afghanistan and the regional security contagion', in Afghanistan-Challenges

and Prospects, ed. S. Bose, N. Motwani and W. Maley, Routledge, London, 2018, pp. 219-40.

33 L. Miller, 'A peace "surge” to end war in Afghanistan', New York Times, 23 July 2017.

34 E. Cameron and and J. Kamminga, Behind Closed Doors: The Risk of Denying Women a Voice in Determining Afghanistan's Future, Oxfam International, Oxford, 2014. 
that 80 per cent of Afghans had 'no sympathy at all' for the Taliban. ${ }^{35}$ The United States, unfortunately, brings some baggage to the table on this issue: on 3 October 1996, the US Assistant Secretary of State for South Asia, Robin Raphel, notoriously stated in an interview for the BBC that 'We have no quarrel with the Taliban in terms of their political legitimacy or lack thereof' ${ }^{36}$ Talk of 'talking to the Taliban' has now been around for more than a decade, ${ }^{37}$ and nothing of substance has come of it. This alone should make one wary of overestimating what negotiations of this kind are likely to deliver. If diplomacy has a role to play, it is in bringing concerted pressure to bear on Pakistan to cease its destabilisation of Afghanistan and to act as a responsible member of international society.

It is highly unlikely that the Taliban could overthrow the Afghan Government by a grinding military campaign of the kind that Soviet forces mounted from 12 January 1945 to seize Berlin. That has never been the main danger that the Afghan Government faces, and it is not in general the way that regimes in Afghanistan change. The danger for the Afghan Government is more insidious. It is that simultaneous threats to a number of towns such as Kunduz and others of similar significance could trigger a 'cascade', ${ }^{38}$ in which actors who did not like the Taliban might nonetheless calculate that the Taliban were well on their way back to power and that it would be opportune to switch sides. It was cascades of this kind that brought about the collapse of the communist regime in late April 1992 and the fall of the Taliban in November 2001. This is where a continuing foreign presence could be psychologically critical. As long as international actors affirm a commitment to the survival of the post-2001 political order and retain forces on the ground that make such a commitment seem credible, a cascade is unlikely on the whole to eventuate.

In conclusion, is Afghanistan, now, of anything more than academic interest to most Australians? Perhaps not, but there are some rather good reasons why Australia should retain a focus on what is happening in the country where so many ADF personnel served and precious lives were lost. No one should underestimate the dangers that could flow from a spreading perception that the international enterprise in Afghanistan after 2001 had

35 Asia Foundation, Afghanistan in 2017, p. 228.

36 Cited in W. Maley, The Afghanistan Wars, Palgrave Macmillan, New York, 2009, p. 90.

37 W. Maley, 'Talking to the Taliban', World Today, vol. 63, no. 11, 2007, pp. 4-6.

38 C.R. Sunstein, Laws of Fear: Beyond the Precautionary Principle, Cambridge University Press, Cambridge, 2005, pp. 94-102. 
failed. At the very least, refugee movements out of Afghanistan, already very substantial, ${ }^{39}$ could be expected to increase. Much more dangerously, just as the Soviet withdrawal from Afghanistan in 1989 prompted radical Islamists to claim that the lesson was that religion was a force multiplier that could defeat even a superpower, so a perceived Western failure in Afghanistan in the 21 st century could easily inject similar claims into radicals discourse directed at impressionable ears. But perhaps most dangerously of all, extremist groups in Pakistan such as Lashkar-e Toiba might well be tempted to try another major terrorist strike against India, comparable to the November 2008 Mumbai attacks. Were this to occur, no one could be sure exactly how India under Prime Minister Narendra Modi might react. The risk of a serious escalation in conflict between India and Pakistan could certainly not be ruled out.

39 W. Maley, What is a Refugee?, Oxford University Press, New York, 2016, p. 1. 
This text is taken from Niche Wars: Australia in Afghanistan and Iraq, 2001-2014, edited by John Blaxland, Marcus Fielding and Thea Gellerfy, published 2020 by ANU Press, The Australian National University,

Canberra, Australia.

doi.org/10.22459/NW.2020.16 